
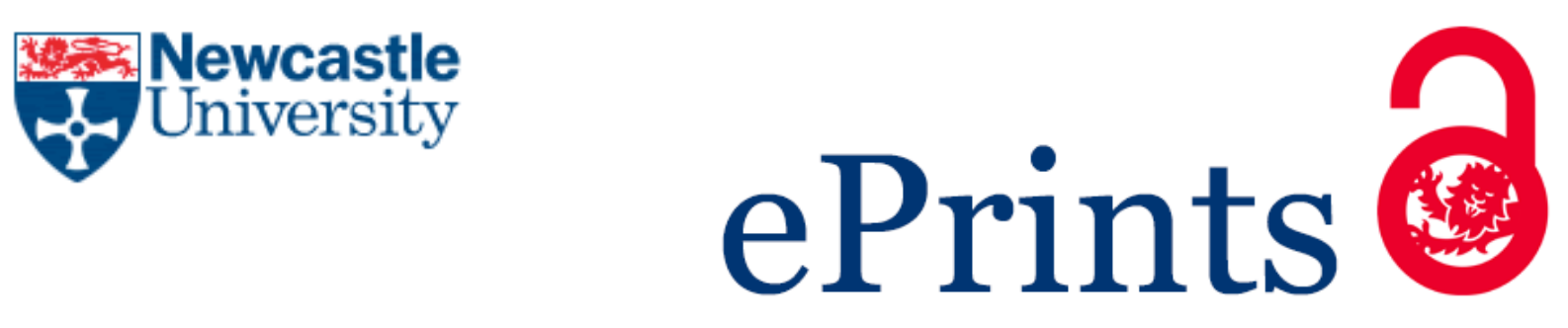

Meliou E, Edwards T.

Relational practices and reflexivity: Exploring the responses of women entrepreneurs to changing household dynamics. International Small Business Journal (2017)

DOI: https://doi.org/10.1177/0266242617724858

\title{
Copyright:
}

Copyright @ 2017 The Authors. Reprinted by permission of SAGE Publications

Date deposited:

$07 / 11 / 2017$ 
International Small

Business Journal

\section{Relational practices and reflexivity: Exploring the responses of women entrepreneurs to changing household dynamics.}

\begin{tabular}{|c|c|}
\hline Journal: & International Small Business Journal \\
\hline Manuscript ID & ISB-17-0061.R2 \\
\hline Manuscript Type: & Full Paper \\
\hline Keywords: & $\begin{array}{l}\text { gender, family, reflexivity, household dynamics, entrepreneurship, women, } \\
\text { agency }\end{array}$ \\
\hline Abstract: & $\begin{array}{l}\text { This qualitative study explores how and why women, positioned as } \\
\text { mothers, wives or carers, navigate changing household dynamics, related } \\
\text { to care and reproductive resources, and become entrepreneurial. Drawing } \\
\text { on relational reflexivity, we show how women's embodied, intimate } \\
\text { relations with important others in the household form the focal point for } \\
\text { entrepreneurial activities, and offer evidence of their entrepreneurial } \\
\text { agency. Our analysis reveals the emergence of three relational practices } \\
\text { that result in a new venture as the entrepreneurial response of women. We } \\
\text { critically evaluate normative analyses on gender, entrepreneurship and } \\
\text { household. }\end{array}$ \\
\hline
\end{tabular}




\section{Relational practices and reflexivity: Exploring the responses of women entrepreneurs to changing household dynamics}

\section{Introduction}

While scholars have recognised the household as a context built on familial relational ties that influence entrepreneurial experience and venture development (Alsos, Carter and Ljunggren, 2014; Renzulli, Aldrich and Moody, 2000), it is also evident that the private domain has been devalued and poorly understood. Feminist theorists have exposed how gender roles, related to caring and motherhood, have been assumed to limit the possibilities for entrepreneurial agency, and impact on women's access and positioning in organisational settings (Calas, Smircich and Bourne, 2009). Women have been associated with the body and the work of intimate care for the bodies of others (Shilling, 2003), and therefore often understood as disruptive and unwelcome, transgressing the social norms by bringing the private world of reproduction (Ashcraft, 1999) into the public sphere.

We critically evaluate such assumptions in an effort to dispel the misconception that gendered structures automatically distort or act as a break on venture creation. Our research objective is to explore the different ways changing household dynamics (birth, separation, family upheaval) situate the entrepreneurial opportunities that can face women living their lives as wives, mothers and/or carers. Women, as a category, form the basis of our analysis; however we argue that actors are not social dopes but rather are to differing extents active in the way they confront social structures (Clegg, 2006). Following work in realist social theory we contend that persons make reflexive choices about what matters. Reflexivity allows us to explain different motivations and how choices are made because 'agents have to diagnose their situations, they have to identify their own interests and they must design projects they 
deem appropriate to attaining their ends' (Archer, 2003: 9). Households that are constituted by relational ties exist as a feature of the relational reflexivity of women constituted by their gendered selves (as wives, mothers and or carers) in respect of the important others (partners, husbands, children, siblings) with whom they share their personal lives and concerns, throughout their life course (Marlow and McAdam, 2012; Donati and Archer, 2015). Thus, we argue that women's familial roles involve an embodied, intimate relationship between mother and child, spousal partners and caring roles that can form the basis of a shared modus vivendi - the realization of a way of life they would find satisfying and sustainable - whereby conceptions of familial care motivate and frame ventures that at one and the same time builds on and reframes the foundations of the household in their lives.

We contribute to research on gender, entrepreneurship and the household, by invoking relational reflexivity to explain the entrepreneurial responses of women whose lives are affected by changes in the household, and negate categorizations imposed on them through ways that emphasize the 'motivations and agency of actors in society' (Wallace, 2002 : 275). Rather than seek to understand the interconnectivity of household-business regarding resource acquisition and business growth, we follow the recommendation of Jennings and Brush (2013) by considering the significance of the relational dimension of the household as the focal point for entrepreneurial activities, through the conceptualization of the relational configuration of changing household dynamics (Elder, 1994; Emirbayer, 1977). Our empirical analysis reveals three agentic relational practices 'Recomposition', 'Separation' and 'Consolidation'. These are not mutually exclusive but rather stem from the configuration of household dynamics across the life course, and result in a new venture, as the active entrepreneurial response of women. The article is structured as follows. First, we begin by considering recent work to frame discussions of gender, entrepreneurship and household. Second, we offer an elaborated explanation of the links between life course trajectories and 
relational reflexivity. Third, we provide details of our sample, methods and data analysis. In the fourth section we present our findings and analysis on agency and responses of women entrepreneurs to household dynamics. The last section concludes.

\section{Gender, household dynamics and entrepreneurship}

The manner in which family and household influence business activities has been explored at length both by researchers studying family enterprises (e.g. Discua Cruz, Howarth and Hamilton, 2012) and enterprising households (e.g. Alsos et al, 2014; Carter, 2011; Jayawarna, Rouse and Macpherson, 2014; Wheelock and Oughton, 1996). The household is influential as expectations, hopes or motives and more importantly as networks of family and friends who remain active in actors' lives. Indeed, families evolve over time because new members are born, grown-up children may leave the family home, couples may separate and older generations pass away (Alsos et al, 2014). Much of this research has focused on the nature of resources and capabilities in terms of financial, emotional or human capital that emanate from household dynamics and influence family-business interactions and decision-making. While this work offers important insights in explaining economic behavior and growth, there is little emphasis on the gendered assumptions and institutional biases associated with changing household dynamics (e.g. birth, death, separation, family upheaval) that affect processes of social valorization and experiences of entrepreneurship, particularly as they relate to care and reproductive resources at certain points across the life course (Jayawarna et al, 2014).

Feminist scholars have recognized gender as a fundamental component of social order with material and ideational effects which functions in society to create differential outcomes 
for men and women (Gunnarsson, Dy and Van Inghen, 2016, Risman, 1998). The way we are embodied enables and constrains our practices, performing social roles and interacting with others (Archer, 2003, Shilling, 2003). Risman (1998:294) emphasizes the structured nature of social life in which "women [and men] fill different positions in institutional settings, work organizations or families"; such positions are associated with various social roles and cultural expectations regarding the rights and duty of action which are critical in terms of resource distribution - whether resources are defined as access to opportunities or actual material goods - and experiences of work. Studies have documented how gender and entrepreneurship lie at the intersection between the private world of home and family and the public world of business and work (Bourne and Calás, 2013; Eddleston and Powell, 2012; Lewis, 2013). Women are involved in the bodywork of intimate care of others bringing the private world of reproduction (Ashcraft, 1999) into the public setting of organization. Women's 'embodied potential for maternity' (Gatrell, 2008: 2) may thus render them unwelcome within professional settings where they are defined by their reproductive capacity, which evokes 'a sense of woman as saturated by her body and existing only in and through her body' (Witz, 2000: 11).

Gender roles instilled by gender socialization processes, and enforced throughout the life span by the gendered nature of work, organizations, and institutions (Ahl, 2006) result in different household and labour market positions, creating a sexual division of labour (Bradley, 2007). Research suggests that men are prescribed greater responsibility for breadwinning and women greater responsibility for the household, family and care giving, while institutions reward and support their labour differently (Jennings and Brush, 2013). In this context, women's entrepreneurship has been associated in many cases with homeworking and the label of 'mumpreneur' (Ekinsmyth, 2011), as a way that enables women to determine the conditions of labour and secure, as a result, flexibility around the execution of business 
and domestic responsibilities. However, such arguments are not 'a cause for celebration' (McRobbie, 2009: 157) as there are detailed accounts of how domestic and care responsibilities are not something that women overcome on the way to entrepreneurial success (Lewis, 2015). Women entrepreneurs may commonly conduct business while caring for children/elderly persons simultaneously or invest nonstandard hours in their business (Dy, Marlow and Martin, 2017). Gender roles are therein built into the organization of life, with mostly women to retain the organizational role of the household (Acker, 2006), regardless of woman's income or career status (Thébaud, 2016).

It has been demonstrated these social biases and gendered expectations of domesticity are detrimental for women in terms of creating or growing new ventures (Bourne and Calás, 2013; Bruni, Gerardi and Poggio, 2004). Hence, those who do not conform to the normative entrepreneur - an unencumbered male professional - find their legitimacy constrained by their subject position (Jayawarna et al, 2014). Not surprisingly, wives, mothers or carers are, as a result, 'already culturally devalued identities' (Bourne and Calás, 2013: 435), opposing the view of what an entrepreneur should be (Ogbor, 2000). Household dynamics (birth, death, family upheaval) associated with the "skill in mothering and its metaphorical extensions" (Haraway, 1990:36), such as care and familial responsibilities for others, precipitate inequalities that position women in the household as 'Othered'. Our aim is to contribute to this research by exploring how women positioned as wives, mothers or carers in the microenvironment of the household make sense and navigate changing household dynamics that require them to find new ways in which to adapt and develop their household relations that can also create economic outcomes. To develop such arguments we introduce relational reflexivity (Donati and Archer, 2015), which enables us to consider women's actions within the social contexts they find themselves. 


\section{Life course trajectories and relational reflexivity}

Recognizing the importance of context in studying entrepreneurial activities has led scholars to support the notion that individual's life transitions and events have a bearing on entrepreneurial intentions and career dynamics (Davis and Shaver, 2012). More specifically, whilst women entrepreneurs may share a common basis for their experiences by virtue of their social position within social hierarchies, including the household, (Gunnarsson, 2011, Bradley, 2007), their actions are influenced by various intersecting structural and cultural contexts in which they are embedded over their personal, family and business life courses (Elder, 1994). Studies of social exclusion in entrepreneurship have addressed how issues of race/ethnicity, and class among others complicate those of gender, and may affect the set of action alternatives (Essers and Benschop, 2009). In turn a marginal positionality - for example women with caring responsibilities and people of color whose actions are challenged by hegemonic conception of the entrepreneur-constrains the accrual of human, social and economic capital, posing structural barriers to entrepreneurial activity (Dy et al, 2017). These are expressed in family and background relations, personal histories and migration that some women experience during their life-courses (Carter, Mwaura and Ram, 2015). Put simply, the life course of individuals is embedded in and shaped by socio-historical influences expressed through shared relationships over individual's lifetime. However, and importantly, women's entrepreneurial actions are not fully determined by their structural and cultural contexts but also rely on the active agent (Clegg, 2006) creating 'gendered choices' (Risman, 1998: 297), subjectively interpreted courses of action within the structurally conditioned space of possibilities in which they find themselves.

Archer's $(2003,2012)$ work on human reflexivity adds considerably more depth into this analysis because reflexivity echoes the past experiences and life trajectories of actors. 
Contrary to theories of reflexivity in late modernity (Beck, Giddens and Lash, 1994) that associate reflexive capacities with increased individual expressivity and the decline in the significance of social structures (such as gender, race, class) in shaping life experience, Archer (2012:6) highlights the intensified role of structural and cultural contexts considering reflexivity 'as the process mediating the effects of our circumstances upon our actions'. Through their reflexive deliberations actors assess social demands and choose to act in ways that allow them fallibly to satisfy personal concerns they subjectively value. More recent work by Donati and Archer (2015) has extended ideas on reflexivity to offer an assessment of the relational subject. This they define as someone who is 'constituted by the relations he/she cares for, that is the subject's concerns' (2015:55). Lives are lived interdependently (Elder, 1994) and the relational organization of close relationships affects all household members and their interactions (Rouse and Kitching, 2006). Donati and Archer (2015:153) argue that 'relational reflexivity consists in orientating the subjects to the reality emergent from their interactions by their taking into consideration how this reality is able to feedback onto the subjects'.

Articulated through the lens of relational reflexivity, women entrepreneurs in our study positioned as mothers, wives or carers negotiated the household dynamics associated with care and reproductive resources in relation to important others, in ways they deemed to be relationally best in order to sustain the 'relational goods' generated in the household. This is how women entrepreneurs make what has been described as imaginative contact with a possible opportunity' (Ramoglou and Tsang, 2016: 424). Based on the conceptualization of the relational configuration of household dynamics we identify three emergent relational practices that reveal how women in our sample, by being relationally reflexive, endorsed their personal projects and concerns linking household gendered structures to their agency. 


\begin{abstract}
What we see are business start-ups with an emergent effect; that is, they are built on symbolic exchange and were created as a response to 'satisfy primary needs' in the household.
\end{abstract}

\title{
Methodology
}

\section{Research context and participants' profile}

Our orientating research question started with asking the following: "how might we conceive of entrepreneurship in the context of women positioned as wives, mothers or carers, confronted with household dynamics, such as birth, separation, death or family upheaval?" This necessitates an understanding of the relational configuration of the household and an examination of the women's relational practices that enable us to explain how their actions mitigate the gendered structures of changing household dynamics. Our qualitative, interpretative study was designed to capture the meanings that women attach to their choices (Archer, 2012) and provides insights into substantive events and experiences forming the basis for considering in detail the interplay between contexts and actions (Suddaby et al, 2015). We aim to explore women's gendered selves, and enable their experiences to be studied without comparison to an 'unmarked male template' (Jackson, 2012:1001) which negatively affects how their actions are perceived (De Bruin, Brush and Welter, 2007; Ahl, 2006). We recognize that women entrepreneurs are a heterogeneous population (Hughes et al, 2012), their household resources do vary (Dy et al, 2017) and the character of women's entrepreneurial activity itself, including the size and location of their ventures, is often contingent on their family situation (Aldrich and Cliff, 2003, Losocco and Bird, 2012). Our goal is not to disentangle these social factors that certainly affect their business performance and growth, but to explicate their active entrepreneurial responses under conditions of life transitions they all experience in their life course. 
In this sense, we see considerable value in exploring entrepreneurship as a reflexive process of engagement revealing the deliberative capacities of individuals in different circumstances as opposed to a largely economic endeavor (Suddaby et al, 2015). To explain this process, data were collected by means of in-depth biographical interviews, through a life history methodology (Chamberlayne, Rustin and Wengraf, 2002). Biographical research has the merit of aiding the task of understanding major social shifts by taking into account how novel experiences are interpreted by persons within groups and institutions (Denzin and Lincoln, 1994). From a feminist framing, biographical interviews offer the potential to recognize the diversity and plurality of women's lived experiences and enhance their visibility (Lather, 1991). In turn, they encourage a reflexive understanding of the relationship between individual action and social structure (Archer, 2003) recognizing the part gendered selves play in constructing structures as well as being mediating by them (Stanley, 1993). To approach our participants we contacted women entrepreneurs' networks in the South of England through university's knowledge exchange networks and business partnerships. Additionally, the 'snowballing' method was used to contact acquaintances of already participating women owner-managers. The 15 interviews reported here are part of a project focusing on women business owners' lives, interests and experiences as a basis for knowledge construction. In the sample, participants were all drawn from the UK and ranged in age from 28 to 53 years. They are all white native born (Byrne, 2006). Thirteen interviewees were married and two divorced at the time of the interview. Of those interviewed nine had one child or more. Participants' firms represent various sectors including, landscape design, marine engineering, marketing, automotive services, construction, biotechnology, consultancy, events management, public relations and communication. Table 1 below details the backgrounds of participants. Pseudonyms are used to protect participants' identity and privacy. 
'Insert Table 1 Here'

The first author collected the biographical accounts in the participants' workplace or her office. Each participant was asked to tell a life story focusing on their current and previous working/life contexts from the point of early aspiration and natal background through to their education and current family situation and employment. Biographical interviews tend to begin with an open-ended question such as, 'Can you take me through your life and employment, starting with information of your natal background, taking into account significant life experiences and employment transitions?' To enhance the depth and complexity of the accounts being developed, our interchange was informed by an analytical framework with guide questions and suggestions of probes and directions for further discussions. This allowed us to expand upon key themes and ensure a degree of standardization among participants (Chamberlayne et al, 2002). Participants reflected upon themselves in relation to their work and life situations explaining how in their own subjectivity made decisions - for instance if they had a child or experienced some other significant family or life transition - and their current understanding of work and personal life within the objective social situations they found themselves. It was following discussions with the second author that both authors came to agreement that such representations of life transitions provided access to each individual's rehearsal of their own 'project', how they fitted into the actions chosen as well as the outcomes of their endeavor. The interviews lasted 90 to 150 minutes each, were tape recorded, transcribed and sent back to participants for possible corrections (Oliver, Serovich and Mason, 2005).

\section{Data analysis}


We analyzed our data using an iterative process (Edwards, O’Mahoney and Vincent, 2014), moving back and forth between the data and the existing literature to capture the gendered structures under which women entrepreneurs found themselves and better understand their actions. We stress that the first author initiated the interview as a universityaffiliated female who asked questions of self-employed females. The similarity of being both professionals and females eased the discussion of gender issues. The second author, who was not involved in the interaction with participants, was engaged in the analysis and interpretation of these accounts. This allowed us to trace the ramifications of participants' actions in wider contexts and contribute to critical scrutiny and theorizing of transcripts. Data analysis was undertaken in three stages.

First, a coding framework was constructed by the researchers using conceptual categories as thematic codes identified in the literature relating to gendered structures, household dynamics, household/family relations, and life/career decisions. Following this, we coded the transcripts and extended it to include any new themes founded in the specific interview (Holton, 2007). At the end of this first step we had a number of primary codes that summarized the conditions that influenced women entrepreneurs' situation, the household dynamics, and the relational configuration of the household. This enabled us to interrogate the literature and primary data to isolate text extracts from across the range of participants.

In the second step, we sought a deeper structure in this array (Gioia, Corley and Hamilton, 2013). We asked how the identified primary codes could help us understand women entrepreneurs' projects and actions, including options not taken, and the justification of the actions they took. We consequently compared our primary codes across interviews and revisited the data using tables to facilitate this comparison. For instance, we developed individual overviews to better understand women's main concerns and decisions in relation to household dynamics. At the end of this stage we had generated second order themes that 
summarized recurrent patterns of relational concerns associated with women's roles as wives, mothers or careers.

In the third and final step we analyzed how the above characteristics were related to the entrepreneurial ways women employed to respond to household dynamics. We distilled from the data the ways the above sub-themes associated with women's roles were combined, including variations within groups. We went back and forth using different definitions of practices to group cases according to the ways that women in our sample navigated relational concerns, such as entry or exit, in their households. This process helped us review each biography and led to the identification of three relational practices 'Recomposition', 'Separation', and 'Consolidation'. We use Figure 1 to feature our data structure for emergent relational practices.

\section{'Insert Figure 1 Here'}

Our analysis is not irreducible merely to giving information about a succession of events but relates to the way women interpret, understand and make sense of their lives and thereby initiate action. Unpacking these practices emphasizes the autonomy of agents showing how relational reflexivity is constituted in practice. The data presented below are not put forward as an illustration of findings or conclusions (Goia et al, 2013); rather they are offered as a means of stimulating a discussion around the issues of gender, entrepreneurship and household, to explain how women entrepreneurs, positioned as mothers, wives or carers, confound boundaries that mark them as 'the other'.

\section{Emergent relational practices: women entrepreneurs negotiating household dynamics}

The biographical narratives of many of our participants offered insight (albeit partially) into the transitions surrounding their personal lives as they struggled to build and sustain family life as a feature of the household. Confronted by household changes associated 
with care and reproductive resources, including separation, child birth, unemployment, financial instability and crisis these women help to illustrate relational feedbacks in respect of these shifts in circumstance that highlight the transformative effect of the household as a context for entrepreneurship (Calás et al, 2009).

The transformative consequences of the feedback loop into the relational dynamics of the household confirm the role of each of the women in subjectively choosing to respond to these changes and in the nature of the family relational composition because such actions are a feature of the subjects and the social ties, as mothers, wives or carers, that bind them together. But, this is not a pneumatic process: 'the social relation is intrinsically reflexive, in the sense that it "is always bent back" on to the subjects that are in the relation. However, reflexivity can be minimal, impeded, distorted, or fractured and in that case so, too, will be the relationality between the agents/actors' (Donati and Archer, 2015: 29). Here we argue the reflexive mode of the women in relation to significant others entailed a positive feedback because they actively considered interactions on the basis of prior life course experiences and because they deliberated the impact of new ways of doing things for what might follow.

We specify three relational practices characterizing how some women, positioned as wives, mothers or carers, responded to changing household dynamics. These reveal the reorganization of relations to sustain the 'relational goods' that created normative conformity in the midst of household dynamics. In this context, we see relational subjects - women positioned as wives, mothers or carers - operating on a personal - relational register that inculcate gendered selves (Risman, 1998) in ways that are subversive and have positive entrepreneurial outcomes (Calás et al, 2009).

\section{Relational Re-composition}


Relational re-composition explains how some of our participants interjected to establish a new enterprise with their marital partners when confronted with household instability. We are interested in the concerns emerging from changing household dynamics and how these transitions can shape women's entrepreneurial responses. As shown in many of the women's accounts their actions were deliberate because instability to the family (usually in terms of lost income) required new ways to overcome the resulting household dissonance. For Risman (2004:431) 'constraints are, of course, an important function of structure, but to focus only on structure as constraint minimizes its importance'. Under these circumstances, some of our women interjected showing how their experiences, dispositions and hunches were reflexively deployed to head-off a family crisis. The responses of our relational subjects confirm the importance of relational reflexivity that enable them to monitor their circumstances and explain those times when embedded gendered structures are challenged (Al-Dajani and Marlow, 2013).

One of our women, Alex, explains how she 're-composed' her marital relationship to help her husband when he could no longer maintain a regular wage. Alex had, by this time (and before their marriage), built up a client base from her bookkeeping business within her local community appreciating what it meant to start from the bottom-up and juggle family and work life, having also previously been a single parent. We agree with Donati and Archer (2015: 142): "relations both are the "mediation" of prior structural and cultural conditioning and have emergent powers, of causal consequence in their own right and of their own kind'. Alex had an intimate understanding of what it meant to sustain the family in hard times, which her husband lacked (prior conditioning) while the establishment of a joint enterprise with him revealed a 'relational good' that could help stabilize their future (intended causal consequence). The development of this business with her husband whilst she had continued to organize the household around the needs of her children albeit with considerable difficulty, 
had allowed her to develop a role where she used her expertise and love of materials (Alex has a degree in Yacht Manufacture and surveying) to secure the households future, contra adversity. Generating shared relational goods through a business venture allowed them to dedicate time to a shared concern - the security of the household.

“Then my husband got made redundant. It was just really unreliable and feeling, you sent me a slip saying we’re going to get paid $£ 400$ and you’ve put $£ 80$ in my bank account. Like how am I meant to run a household on this? So I threw my toy out the pram one day and said well I'll find you work. If you like painting and decorating and tiling and things, I'll find you work. I've done it for the book keeping; I'll do it for you. It went from me sort of helping out and giving advice and finding the work, to sort of doing all of it." (Alex, married with children)

Like Alex, other participants also adapted to household dynamics related to family upheaval as they experienced it with their partner's job. Paula 'recomposed' her relationship helping her partner with his business to save it from bankruptcy "They were very, very dodgy ground for a long time”. This was essential for their life together, as they had recently acquired a mortgage. Paula had grown up in a council house and was the first in her family to go to university and acquire a degree in Business Management. Having been self-employed sales contractor and advertising magazine owner - she became her husband's much needed bookkeeper as well as assisting with marketing and sales. This collaboration subsequently led them to start a business, which confirmed the business acumen of Paula, who became a shareholder and managing director.

He ran it by himself for a good 2 years and it was difficult because obviously we had to fund from our own money, it wasn't going anywhere. We had a big 
discussion because we're both concerned that by both working for the same company, if something happened, we'd lose the house and everything. After deciding, I said "make me a director then because I'm not closing my company down and having nothing”. He made me a director, $50 \%$ shareholder, all of that and then I took over in the business basically. (Paula, married)

In both cases the threat to the household provided the impetus to monitor what can be termed 'the family's modus vivendi' (Donati and Archer, 2015:144, italics in original). It is also illustrative of the wife as business partner asserting control precisely because they have an innate appreciation of the household-business nexus (Carter, 2011). Transforming the modus vivendi is necessary when events call into question the basis of the relational configuration in the household. Put another way, 'to establish a modus vivendi is initially and deliberatively to design a way of life that the subject reflexively deems worth living and, all being well, subsequently finds can be lived' (Donati and Archer, 2015:134). The relational goods that emerged from the relational configuration of household dynamics indicate the agency of these women as reflexive individuals able to be entrepreneurial.

To understand the scope of entrepreneurship (Calás et al, 2009) it is necessary to realize that our participants' responses are not simply a question of rational choice or use of familial networks to start a business (Renzulli et al, 2000) but, as argued, involves relational subjects - wives, mothers, carers - making active responses to satisfy their concerns in their attempt to confound the gendered structures of household dynamics. We can call this 'dovetailing' of concerns among relational subjects (Archer, 2003) when partners imagined and actualized their version of the future (Ramoglou and Tsang, 2016). Take Suzie, a designer, in her account she notes how her husband, Graham who is an architect recomposed their relationship to support her first project as a freelancer during her pregnancy. Here we see pregnancy as the motivation to change the relational basis of their family that, contrary to 
claims otherwise, created the opportunity to re-compose their lives based on the complementarity of skills, dedication and co-commitment, which led to this business and then a second.

Graham is an architect and me, doing kind of design and space layout and this kind of thing. It's good for meeting our two skills. So in the seven years, he has been my employee really in terms of what we've done (Suzie, married with children).

Suzie's example illustrates how some women in the household by leveraging relationships, and using the synergy between the household and career projects helps to extend their horizons to respond to the gendered structures of household dynamics, as in pregnancy. In each case, these women actively confounded the changes to the household; that is, they were not stymied by events, but they co-created relational compositions that resulted in a business growing out of mutual interests and skills. Their upbringing backgrounds and life trajectories enabled them to combine a variety of resources at hand, such as skills and knowledge, in ways that allowed them to embrace the contextual discontinuities (e.g., pregnancy, family upheaval) they encountered and thus extend the solutions available to them in order to create and grow their firms and personally succeed. Here we see how the action of women, whose lives are shaped by their caring roles was directed toward a shared ideological concern (relational good) about sustaining the family that illustrates how they deliberated on what had happened and then what needed to shift, initiating a business to secure the family's future. Their relational reflexivity was aimed towards the partnerships and how this might be changed to respond to household dynamics they faced. In this sense, the relational goods create solidarity in the household and the context for the new business start-up.

\section{Relational Separation}


Relational separation explains how tension is eased and affectivity is sustained as a result of exit through separation or death of family members. In the above section the shared concerns show the potential for entrepreneurial opportunities built around transformed marital relationships. However, concerns are not confined to re-combinations of existing cohabitants but can also follow transitions and events that are connected to social entropy or the separation of family members that create what can be termed 'relational evils' (Donati and Archer, 2015). Households not only encompass ties of solidarity and affection, they are also points of tension (Alsos et al, 2014). The entrepreneurial responses of women in our study - positioned as wives, mothers or carers - are thus borne out of familial histories to sustain the relational goods associated with the affective roles the household plays (Folbre, 2001). Such relational goods follow breaks in the constitution of family's relational composition that invites new dialogue about what matters to those members that remain.

Linda illustrates how she set up a business in automotive services for women, as a result of her daughter moving out of the home. There is an inherent relationality to this mobility. Linda and her husband felt responsible for her adult daughter in spite of the physical distance between them. Providing practical support at a distance through the business for equivalent mobile females suggests parenting beyond the typical age of dependency, which eases the emotional strain and indicates how she adapted to respond to this familial change. Here we see changes in the family relational composition, associated with a separation, propelling Linda, as wife and mother, to conceive of a new business that lead to her founding, owning and becoming the managing director of an award-winning firm that has attracted national attention for focusing on the needs of women motorists. In her account she acknowledges the tension accompanying the exit of their daughter:

A combination of factors then occurred, but the main one was that our stepdaughter, Paul's daughter Emma, aged at that stage early 20s, who had 
been living with us, left home with her 3-year-old car to go and live in the north of England, and it dawned on us that, despite the fact that she had been given a very basic maintenance instruction kit from her father, she was going to be quite ill-equipped to sort out and look after her car herself. This caused her father a great deal of stress. I then started to look at how it might be possible to offer a package of motoring services specifically for women (Linda, married with children).

The shift from worries about her daughter to respond and start a new business confirm that this move into a 'masculine' industry (Alvesson and Billing, 2009) was not a passive process but illustrates how relational reflexivity has the potential to navigate seemingly significant barriers to action. The household is significant, because breaking it apart in this way set in play emotional responses among those physically co-located that confirmed how their child's 'well-being' mattered to them, which created the energy to transpose her worries into creating a new business; that is, where Linda, as mother and relational subject, confirms what is important to her.

In turn, some of our women decided to be entrepreneurial despite events that created severe emotional trauma in the household calling into question the way of life they had deemed worth living. On such occasions, separation seemingly provoked a move to negotiate household dynamics, which served as a 'buffer' allowing them to offset the ill-effects of a tense period of life. Rhian, founder and managing director, explains the antecedents to her decision to start her PR and Communication Company, which was the result of a miscarriage.

I had a miscarriage and I was quite stressed out and I thought I think this is the time really to do something different... I don't think [my husband] was earning what he earns now and I was still really the primary breadwinner I supposed, but he was completely supportive. If it all went horribly wrong, I would just say 
I gave up work for a little while to get over the miscarriage to seem like a starting school. Well that was 7 years ago. Things went really well. (Rhian, married with children)

As with the case of Linda, being confronted with a major separation in the household provoked responses that indicate her reflexivity and choices about the future of the household, which was defined by a relational break. Entrepreneurship was a positive response to the upset brought about by life changes that was a chance to ease emotional tensions. The relational configuration of household dynamics is not fluid enough to just adjust to changing transitions; it requires resilient selves, as some of our women entrepreneurs demonstrate. They are a key feature of the 'gendered choices' (Risman, 1998), resulting from women's position within a social world where gendered roles shape experience and understanding. How they are manifest in action is mediated by reflexivity as a feature of past actions and present concerns and in this sense they are shared concerns with those significant others in the household.

\section{Relational Consolidation}

In our sample, two of our women entrepreneurs used to be a single parent, and another one a carer. Relational consolidation -'keeping in touch' with their important others in an attempt to pursue more satisfying living arrangements - offered affirmation about the choices made such as leaving a lucrative job to start anew. Through the accounts of these women, positioned as single parents/carer, we show how they managed to embrace the household dynamics they faced and flexibly, using creative thinking, to enact opportunities to start their own businesses.

In her account Laura, founder of a successful HR company, explains that her career had reached a peak in the UK. Working abroad was considered the best plan for her career at 
the time but not the right choice for her life "I wanted to feel in control of my life rather than work being in control of me and that was a really important part for me. I wanted to be in control of where I lived". When Laura founded her business, keeping in close contact with mother - her father was not around - was essential.

An international role wasn't the right time for me in my life. I wasn't married at the time, so I haven't got any children. I've got stepchildren now, grandchildren, but I haven't got any of my own. But I felt that I needed to spend more time with my mother and I also felt I wanted to focus on my career in this country. So I decided to take redundancy and then set the business up in 2004. (Laura, married)

Similarly, for Alex, the birth of her daughter, Reeva, and quick departure of the father ensured she would need to be self-reliant, as "suddenly I had no job, a baby, no house”. As a single mother, the creation of a kinship bond with Reeva shaped her appraisal of the career options available to her because "time with my baby whilst she was small was far more important than money”. However, she was not discouraged by this as she did a home study course as a bookkeeper, although "I was just terrified as to whether or not I'd make it work." For Alex, her household required a different approach to her career and this was mediated by her role as 'bread-winner' and 'mother'.

Yeah I studied while I was pregnant and shortly after I had Reeva I just set up, I just went door to door with some business cards and all the local businesses, speaking to as many people as I could and leaving my business cards everywhere. I'm a book keeper, I can do your books? So I was sort of doing the studying and building the client base and just working every evening, so when baby went to bed I went into the spare bedroom and it's just data entry really 
isn't it, book keeping. (Alex, married with children)

Consolidating relationships helps to explain the motives and 'gendered choices' of some of our women entrepreneurs with regard to what was deemed as both relationally possible and best for the household, and reflects the agency of women in forming new ventures. As with the other practices in this appraisal the make-up and position of relational subjects in the household can take on many different forms and can generate different dynamics related to concerns - family unity and family time - over the future constitution of the household, in the context of gendered structures women operate. Consolidation is important in giving 'ontological security', which is to carve out a sense of continuity and cohesiveness in the shared lives of those in the household (Giddens, 1991). Ensuring this 'relational good' through consolidation can be seen as a way to respond to separation in the relational structures of the household. Relational concerns co-exist in ways that create their own dynamics that can enable women, as wives, mothers or carers, to negotiate the gender structures of household dynamics as an outcome of the interactions of the different household relational configurations.

\section{Discussion}

James (2012) argues that research on women entrepreneurs needs to extend into new directions to focus on the successes rather than the problems experienced. Within this article we aim to contribute to this endeavor through the exploration of how and why women, positioned as wives, mothers or carers, negotiate and respond to household dynamics. Figure 2 illustrates a summary of our framework and the three relational practices we identified. We present a number of contributions to this debate, outline suggestions for future research and note the limitations of our arguments.

'Insert Figure 2 Here' 
Our analysis of the literature revealed how gendered expectations of domesticity create a sexual division of labour in care (Bradley, 2007) which reproduces gendered structures that devalue practices and activities associated with the private and the feminine (Calás et al, 2009; Gatrel, 2013, O’Hagan, 2014). As Acker notes (1992: 255) 'these [gendering] practices and relations, encoded in arrangements and rules, are supported by assumptions that work is separate from the rest of life and that it has first claim on the worker. Many people, particularly women, have difficulty making their daily lives fit these expectations and assumptions'. This view of women entrepreneurs contrasts them with the archetypical male entrepreneur (Ogbor, 2000). As a consequence, women entrepreneurs exist at the periphery of recognized entrepreneurial activity, construed as survivalist and noneconomic agents while their new ventures are deemed as less legitimate and less likely to succeed (Marlow and McAdam, 2015).

In our study, we explored the gendered paths of wives, mothers and carers and found that such structures do not undermine wholesale the role of women entrepreneurs. Research on the household positioning of women entrepreneurs has been limited. Using Archer's (2003, 2012) work on reflexivity in the context of changing household dynamics (Alsos et al, 2014) sensitized our analysis to advance this literature by illustrating why and how those women entrepreneurs can respond successfully to significant life transitions and perhaps 'overcome the taken-for-grantedness of their socially constructed environment' (Suddaby et al, 2016: 3). In doing so, we cast our gaze on not just the individual, as a reflexive individual, but also the relationships that inform and constitute the context within which new futures are imagined and actualized (Ramoglou and Tsang, 2016).

First, our findings suggest relational reflexivity (Donati and Archer, 2015) is crucial in explaining women's entrepreneurial responses, positioned as relational subjects in the household, offering an alternative understanding to studies focusing on the uniqueness of the 
entrepreneur, which marginalize non-hegemonic actors. The context of entrepreneurship shows that there is more inequality and exclusion in relation to individual's position within social hierarchies, which affects resource accrual (Jayawarna et al, 2014, Dy et al, 2017). In this article, we argue that it is essential to maintain the analytical distinction of structure and agency (Archer, 2003), which allows us to explore the capacities needed to navigate household gendered structures. Thus, our study advances women entrepreneurship theory regarding the role of family and household (e.g. DeMartino and Brabato, 2003) by exploring the entrepreneurial actions of women as conditioned action (not determined), which plays out in relation to their reflexivity. This is important because reflexive abilities collide with the multiple household gendered structures that constitute the social context in which women find themselves as the past meets the present. For our participants, structures were "what they confront - and have to grapple with' (Archer, 1982: 463). Analogous to studies that observe how women negotiate their social context (Al Dajani and Marlow, 2013; Essers et al, 2010; Dy et al, 2017) our study shows how through the development of relational reflexivity the actions of women entrepreneurs highlight their agency as they have the power to implement practices they deem appropriate for their lives.

Second, from the data collected three relational practices have emerged that enabled the women to negotiate the changing household dynamics (i) Relational recomposition that lead to a unity of life together, (ii) Relational separation that precipitated enterprising efforts to ease emotional strain, and (iii) Relational consolidation with regard to possible loss of family cohesiveness and an attempt to sustain key relationships to avoid conflicting situations. These practices emerged from our conceptualization of the relational configuration of household dynamics (Elder, 1994) as revealed through the personal biographies of our participants. The examination of the household as a unit of analysis and its impact on resource accrual and business growth though household-business interactions (e.g. Alsos et 
al, 2014, Carter, 2011, Jayawarna et al, 2014) is well documented in the literature, but what is not documented is the focus on 'ends' - not 'means' - as the prime concern of persons who engage in and reflexively monitor their personal projects. As such the relational practices explain women's personal concerns and their attempts to sustain the 'relational goods' generated in the household amidst family transitions. These practices are not only consistent with the family embeddedness idea of entrepreneurship (e.g. Aldrich and Cliff, 2003); they also advance research by identifying the important tract of the relational dimension of the household-business interaction, accounting for the importance of understanding people, their diagnoses and their actions, which are as influential as the structures and institutions that they necessarily engage. This is not an either/or situation; rather, an individual can adopt all three practices depending on the situation in the life course. We have seen, as a result, our participants create and use possibilities to satisfy their personal concerns and thereby in different ways become successful business-women, amidst household gendered structures.

Third, more broadly, our findings suggest how entrepreneurship represents a transformational activity "taking place" in the everydayness of our life, in social interactions and in everyday practices' (Stayaert and Katz, 2004:190). The emphasis is on the link between the actor, their relations, the household and society. Our relational framework avoids looking at the household as separate from normative work spaces and the activities of women as 'economic' or 'non- economic', looking instead at how activities 'connect to each other and would not work without each other' (Glucksmann, 1995: 68). Our study on women as wives, mothers and carers in the context of household dynamics makes evident how entrepreneurship as inculcated in the generation of ideological, emotional and family cohesiveness particularly in times of family disruption that extends ideas of "what else entrepreneurship is and does' (Calás et al, 2009: 553). 
We see broader implications for our work as it calls for a better understanding of the relational subject, which is open to non-deterministic appraisals of action (Donati and Archer, 2015, Kitching and Rouse, 2016). This move coincides with efforts in neo-institutional theory to address the paradox of embedded agency (DiMaggio and Powell, 1991; Friedland and Alford, 1991; Seo and Creed, 2002). What appeared as barriers to business development were overcome precisely because each of these women were enabled due to their gendered biography and social position to imagine and enact a different future. This is not to argue that there is a universal and generalizable female experience, but it is to show how actors confronted by situational discontinuities see scope for agency, as opposed to barriers (Mutch, 2007). In this respect, our work extends recent work on reflexivity in neo-institutional theory (see Delbridge and Edwards, 2013; Edwards and Meliou, 2015; Suddaby et al, 2016) not just because of the move to reinvigorate micro-analyses as opposed to macro-studies but because our work draws attention to gender, which has been profoundly ignored in neoinstitutionalism.

Finally we believe that this debate has much wider implications for entrepreneurship research. Whilst we deployed relational reflexivity to explain that entrepreneurial actions of women embedded in the household, our arguments have theoretical and analytical relevance within different entrepreneurial contexts such as teams or communities allowing for a more nuanced understanding of entrepreneurial actions resulting from shared projects and concerns (e.g. Shalley and Perry-Smith, 2008). Our findings also contribute significantly to the literature on entrepreneurial motivation, as they add nuance to the over simplistic push/pull model (Shapero and Sokol, 1982).

\section{Limitations and future research}


This study, as with most, has some limitations but through identifying them we can also identify interesting avenues for future research. Limitations to the empirical study are acknowledged; there are small numbers in each sub-category (wives, mothers, carers) of women interviewed and thus future research needs to replicate and extend this study. Furthermore, whilst our focus on women's entrepreneurial responses to household dynamics that all of them experience points out their reflexivity, we acknowledge that individuals are reflexive to different degrees (Archer, 2012), which affects their gendered paths and decisions. Attention to different forms of reflexivity presents an opportunity for entrepreneurship scholars to further explore differences between and within the actions of women entrepreneurs and contribute to a more nuanced understanding of the heterogeneity of women entrepreneurs (Hughes et al, 2012). Understanding more about the experiences of women entrepreneurs in the context of the household presents an intriguing direction for future research recognizing the causal significance of relational subjects that are operating through but not determined by social structures.

\section{Conclusion}

In sum, while entrepreneurship research has suggested the significance of household and family in entrepreneurial experience is paramount, contemporary analyses indicate a gender bias that calls into question how women embedded in the household, as wives, mothers and/or carers, overcome inequalities to be entrepreneurial. In this article we explored this paradox and showed how these women, as relational subjects, through self-monitoring and evaluation of their gendered concerns engage in relational reflexivity to overcome the changing household dynamics to sustain relational goods for the household and become successful entrepreneurs. The emergence of three relational practices should stimulate a renewed interest in understanding the entrepreneurial actions of women as conditioned 
action, which takes place in everydayness when individuals see - contra adversity - a chance to actualize a new world.

\section{References}

Acker J (1992) From sex roles to gendered institutions. Contemporary Sociology, 21, 565569.

Acker J (2006) Inequality regimes: Gender, class, and race in organizations. Gender \& Society, 20(4), 441-464.

Adkins L (2003) Reflexivity: freedom or habit of gender. Theory, Culture and Society, 20,6, $21-42$.

Ahl H (2006) Why research on women entrepreneurs needs new directions. Entrepreneurship Theory and Practice, 30, 595-621.

Al-Dajani H and Marlow S (2013) Empowerment and entrepreneurship: A theoretical framework. International Journal of Entrepreneurial Behaviour \& Research 19(5), 503-524.

Aldrich H and Cliff J (2003)The pervasive effects of family on entrepreneurship: Towards a family embeddedness perspective, Journal of Business Venturing, 18, 573-596.

Alsos GA, Carter C and Ljunggren L (2014) Kinship and business: how entrepreneurial households facilitate business growth, Entrepreneurship \& Regional Development: An International Journal, 26 (1-2), 97-122

Alvesson M and Billing Y.D (2009) Understanding gender and organizations, 2 edn. London: Sage. 
Archer M (2012) The Reflexive Imperative in Late Modernity. Cambridge: Cambridge University Press.

Archer M (2003) Structure, agency and the internal conversation. Cambridge: Cambridge University Press.

Archer M (1982) Morphogenesis versus structuration: On combining structure and action. British Journal of Sociology 33(4), 455-483.

Ashcraft KL (1999) Managing maternity leave: A qualitative analysis of temporary executive succession. Administrative Science Quarterly 44(2): 240-80.

Beck U, Giddens A and Lash S (1994) Reflexive Modernisation: Politics, Tradition and Aesthetics in the Modern Social Order. Cambridge: Polity.

Bourne K.A and Calás M.B (2013) Becoming "real" entrepreneurs: women and the gendered normalization of work. Gender, Work and Organization, 20, 425-438

Bradley H (2007) Gender. Cambridge: Polity.

Bruni A, Gherardi S and Poggio, B (2004) Doing gender, doing entrepreneurship: an ethnographic account of intertwined practices. Gender, Work \& Organization, 11,4, 406-29.

Byrne B (2006) White Lives: The Interplay of 'Race', Class and Gender in Everyday Life. New

York: Routledge.

Calás M.B, Smircich L and Bourne K.A (2009) Extending the boundaries: Reframing 'Entrepreneurship as social change' through feminist perspectives. Academy of Management Review, 34, 552-569

Carter S (2011) The rewards of entrepreneurship: exploring the incomes, wealth, and economic well-being of entrepreneurial households, Entrepreneurship, Theory and Practice, $35,39-55$ 
Clegg S (2006) The problem of agency in feminism: a critical realist approach, Gender and Education, 18:3, 309-324

Carter S, Mwaura S, Ram M, et al. (2015) Barriers to ethnic minority and Women's enterprise: Existing evidence, policy tensions and unsettled questions. International Small Business Journal 33(1): 49-69.

Chamberlayne P, Rustin M and Wengraf. T. (eds) (2002) Biography and Social Exclusion in Europe. Bristol: The Polity Press.

Davis A and Shaver K (2012) Understanding gendered variations in business growth intentions across the life course. Entrepreneurship Theory and Practice, 36, 495-512.

DeMartino R and Barbato R (2003) Differences between women and men MBA entrepreneurs: Exploring family flexibility and wealth creation as career motivators. Journal of Business Venturing, 18, 815-832.

Denzin N. K and Lincoln Y. S. (eds). (2000). Handbook of Qualitative Research, 2nd revised ed. London: Sage.

De Bruin A, Brush CG and Welter F (2007) Advancing a framework for coherent research on women's entrepreneurship. Entrepreneurship Theory and Practice, 31(3), 323-339.

Delbridge R and Edwards T. J. (2013) Inhabiting institutions: Critical realist refinements to understanding institutional complexity and change. Organization Studies 34(7), 927-947.

DiMaggio P J and Powell W (1991) "Introduction.” Pp. 1-38 in The New Institutionalism in Organization Analysis, Walter W. Powell and Paul J. DiMaggio, eds. Chicago: University of Chicago Press.

Discua Cruz A, Howorth C and Hamilton E (2013) Intrafamily Entrepreneurship: The Formation and Membership of Family Entrepreneurial Teams, Entrepreneurship Theory and Practice 37 (1), 17-46. 
Donati P and Archer M (2015) The Relational subject. Cambridge: Cambridge University Press.

Dy M.A, Marlow S and Martin L (2017) A Web of opportunity or the same old story? Women digital entrepreneurs and intersectionality theory, Human Relations, 70(3), 286-311

Eddleston K and Powell G (2012) Nurturing entrepreneurs' work-family balance: a gendered perspective, Entrepreneurship, Theory and Practice, 36(3), 513-541

Edwards T. J and Meliou E (2015) Explaining leadership in family firms: Reflexivity, social conditioning and institutional complexity. Human Relations 68(8), 1271-1289

Edwards P, O'Mahoney J and Vincent S (2014) Studying Organizations Using Critical Realism: A Practical Guide. Oxford, Oxford University Press

Elder G.H Jr (1994) Time, human agency, and social change: Perspectives on the life course, Social Psychology Quarterly, 57, 4-15

Ekinsmyth C (2011) Challenging the boundaries of entrepreneurship: The spatialities and practice of UK “mumpreneurs”, Geoforum, 42, 104-114.

Emirbayer M (1997) Manifesto for relational sociology. American Journal of Sociology 103, 281-317.

Essers C, Benschop Y and Dooreward, H (2010) Female ethnicity: Understanding Muslim immigrant businesswomen in the Netherlands. Gender, Work and Organization, 17(3), 320339.

Essers C and Benschop Y (2009) Muslim businesswomen doing boundary work: The negotiation of Islam, gender and ethnicity within entrepreneurial contexts, Human Relations, 62(3), 403- 423

Folbre N (2001) The Invisible Heart: Economics and Family Values. New York: New Press 
Friedland R and Alford R (1991) Bringing society back in: Symbols, practices, and institutional contradictions. In W. W. Powell and P. J. DiMaggio (Eds.), The new institutionalism in organizational analysis (pp. 311-336). Chicago, IL: University of Chicago Press.

Gatrell CJ (2013) Maternal body work: How women managers and professionals negotiate pregnancy and new motherhood at work, Human Relations, 66 (5), 621- 644

Gatrell CJ (2008) Embodying Women's Work. Maidenhead: Open University Press

Gioia D. A, Corley K. G and Hamilton A. L (2013) Seeking qualitative rigor in inductive research. Organizational Research Methods, 16, 15-31.

Giddens A (1991) Modernity and Self-Identity: Self and Society in the Late Modern Age, Stanford, CA: Stanford University Press

Glucksmann M.A (1995) Why 'work'? Gender and the 'total social organization of labour'. Gender, Work \& Organization, 2, 63-75.

Gunnarsson L, Dy M.A and van Ingen M (2016) Critical Realism, Gender and Feminism: Exchanges, Challenges, Synergies, Journal of Critical Realism, 15 (5), 433-439

Gunnarsson L (2011) A deference of the category “women”, Feminist Theory, 12 (1), 23-37

Haraway D (1990) A manifesto for Cyborgs: Science, technology and socialist feminism in the 1980s. In L. Nicholson (Eds) Feminism/Postmodernism, New York, Routledge

Holton JA (2007) The coding process and its challenges. In: Bryant A and Charmaz K (eds), The SAGE Handbook of Grounded Theory (paperback edition). London: SAGE, pp. 265-289.

Hughes K.D, Jennings J.E, Brush, C.G, Carter S and Welter F (2012). Extending women's entrepreneurship research in new directions. Entrepreneurship Theory and Practice, 36, 429442. 
Jackson C (2012) Speech, gender and power: Beyond testimony. Development and Change 43(5), 999-1023.

James A.E (2012) Conceptualizing 'woman' as an entrepreneurial advantage: A reflexive approach. In K.D. Hughes \& J.E. Jennings (Eds.), Global women's entrepreneurship research: Diverse settings, questions and approaches. Cheltenham: Edward Elgar.

Jayawarna D, Rouse J and Macpherson A (2014) Life course pathways to business start-up. Entrepreneurship \& Regional Development 26(3-4), 282-312

Jennings J.E and Brush C.G (2013) Research on women entrepreneurs: Challenges (to and from) the broader entrepreneurship literature? Academy of Management Annals, 7, 661-713

Lather P (1991) Getting smart: Feminist research and pedagogy with/in the post-modern, Routledge: New York.

Lewis P (2015) Postfeminism, femininities and organization studies: Exploring a New Agenda. Organization Studies, 1-22

Lewis P (2013) The search of an authentic entrepreneurial identity: Difference and Professionalism among women business owners, Gender, Work and Organization, 20 (3) 252- 266

Losocco K and Bird S.R (2012) Gendered paths: Why women lag behind men in small business success. Work and Occupations, 39(2), 183-219.

Kitching J and Rouse J (2016) Opportunity or dead end? Rethinking the study of entrepreneurial action without a concept of opportunity, International Small Business Journal, 1-20

Kelan EK (2010) Gender logic and (Un) doing gender at work, Gender, Work and Organization, 17 (2) 174-194. 
Marlow S and McAdam M (2015) Incubation or induction? Gendered identity work in the context of Technology Business Incubation, Entrepreneurship, Theory and Practice, 39(4), $1-26$

Marlow S and McAdam M (2012) Analyzing the influence of gender upon high technology venturing within the context of business incubation. Entrepreneurship Theory and Practice, $36(4), 655-676$.

McRobbie A (2009) The Aftermath of Feminism. London: Sage.

Mutch A (2007) Reflexivity and the institutional entrepreneur: A historical exploration. Organization Studies, 28, 1123-1140.

Ogbor J (2000) Mythicizing and reification in entrepreneurial discourse: Ideology critique of entrepreneurial studies. Journal of Management Studies, 35(5), 605-630.

Oliver D, Serovich, J.M and Mason T.L (2005) Constraints and Opportunities with Interview Transcription: Towards Reflection in Qualitative Research, Social Forces, 84 (2), 1273-1287

Ramoglou S and Tsang E.W.K (2016) A realist perspective of entrepreneurship: Opportunities as propensities, Academy of Management Review, 41(3), 410-434.

Renzulli L.A, Aldrich H and Moody J (2000) Family matters: Gender, networks and entrepreneurial outcomes. Social Forces, 79(2), 523-546.

Risman B (2004) Gender as a social structure: Theory wrestling with activism, Gender \& Society, 18, 429- 450

Risman B (1998) Gender vertigo: American families in transition. New Haven, CT: Yale University Press.

Rouse J and Kitching J (2006) Do Enterprise Programmes Leaving Women Holding the Baby?" Environment and Planning C: Government and Policy 24 (1): 5-19. 
Seo M-G and Creed D. W. E (2002) Institutional contradictions, praxis, and institutional change: A dialectical perspective. Academy of Management Review, 27, 222-247

Shalley C and Perry-Smith J.E (2008) The emergence of team creative cognition: the role of diverse outside ties, sociocognitive network centrality, and team evolution. Strategic Entrepreneurship Journal, 2, 23-41

Shapero A and Sokol L (1982) The social dimensions of entrepreneurship. In C. Kent, D. Sexton \& K. Vesper (Eds.) The Encyclopedia of Entrepreneurship. Englewood Cliffs, NJ: Prentice Hall.

Shilling C. (2003) The Body and Social Theory, Sage, London.

Stanley L (1993) On auto/biography in Sociology. Sociology, 41-52

Steyaert C and Katz J (2004) Reclaiming the space of entrepreneurship in society: Geographical, discursive and social dimensions. Entrepreneurship \& Regional Development, 16: 179-196.

Suddaby R, Bruton G.D and Si S.X (2015) Entrepreneurship through a qualitative lens: Insights on the construction and/or discovery of entrepreneurial opportunity, Journal of Business Venturing, 30, 1-10.

Suddaby R, Viale T and Gendron Y (2016) Reflexivity: The role of embedded social position and entrepreneurial social skill in processes of field level change, Research in Organizational Behaviour, doi.org/10.1016/j.riob.2016.02.001.

Thébaud S (2016) Passing up the job: the role of gendered organizations and families in entrepreneurial career process, Entrepreneurship, Theory and practice, 40 (2) 269-287

Tomlison, J, Muzio,D, Sommerland, H, et al. (2013) Structure, agency, and career strategies of white women and black and minority ethnic individuals in the legal professions. Human Relations, 66, 245-269 
Wallace C (2002) Household Strategies: Their Conceptual Relevance and Analytical Scope in Social Research. Sociology 36 (2), 275-292.

Wheelock J and Oughton E (1996) The Household as a focus for research. Journal of Economic Issues XXX (1), 143-159.

Witz A (2000) Whose body matters? Feminist sociology and the corporeal turn in sociology and feminism. Body and Society 6(2): 1-24.

\section{Biographies}

Elina Meliou, $\mathrm{PhD}$ is a Lecturer in Organizational Behaviour and HRM at Newcastle University London, UK. Her research focuses on the dynamics of leadership, gender and entrepreneurship with particular emphasis on how the actions of actors are negotiated within organizational and institutional contexts. Her work has appeared in journals such as Human Relations and Equality, Diversity and Inclusion, and has been presented in international conferences. She is also the lead researcher for a project on career trajectories of women entrepreneurs funded by the British Academy.

Tim Edwards (Ph.D., Aston University) is Professor of Organisation and Innovation Analysis at Cardiff Business School. His research interests include critical studies of women entrepreneurs, institutional change, innovation and organisational theory. Tim has published in a number of world-leading journals including, Journal of Business Venturing, Organisation studies, Human Relations, Organisation, Journal of Management Inquiry, International Journal of Management Reviews, Management Learning and Urban Studies. He has also won a number of best paper awards from the Academy of Management (USA). 


\section{Table 1}

\section{Characteristics of Respondents}

\begin{tabular}{|c|c|c|c|}
\hline Name & Main Sector/Service & $\begin{array}{l}\text { Marital status at the } \\
\text { time of the interview }\end{array}$ & Education \\
\hline Paula & Landscape design & Married & BSc Health and Fitness Management \\
\hline Alex & Property Services & Married with children & BSc Naval engineering \\
\hline Laura & HR consultancy & Married & BSc Business Management \\
\hline Rhian & PR -Communications & Married with children & BSc Theatrical/ Drama Studies \\
\hline Suzie & Design and Illustrations & $\begin{array}{ll}\text { Married } & \text { with } \\
\text { children } & \end{array}$ & $\begin{array}{l}\text { BA Hons Multi-media Textile Design } \\
\text { MA Illustration }\end{array}$ \\
\hline Kate & Technology & Married & MSc Business Management \\
\hline Caroline & Events Management & Married & BSc Business Management \\
\hline
\end{tabular}




\begin{tabular}{|c|c|c|c|}
\hline Zena & Construction/Building & $\begin{array}{l}\text { Married with } \\
\text { children }\end{array}$ & BSc Law \\
\hline Penny & Social Enterprise & Married with children & MSc arts \\
\hline Linda & Automotive & Married with children & MBA \\
\hline Amanda & $\begin{array}{l}\text { Consultancy- Professional } \\
\text { Development }\end{array}$ & Married with children & BSc Modern languages \\
\hline Erin & Biotechnology & $\begin{array}{l}\text { Divorced with } \\
\text { children }\end{array}$ & Medical Studies \\
\hline Gina & Marine Engineering & Married with children & BSc, MA Engineering \\
\hline Jane & HR -Consultancy & $\begin{array}{l}\text { Divorced with } \\
\text { children }\end{array}$ & MSc social work \\
\hline Heather & $\begin{array}{l}\text { Consultancy }- \text { Social } \\
\text { enterprise }\end{array}$ & Married with children & BA Geography, MSc Economic Development \\
\hline
\end{tabular}


"Then my husband got made redundant... So I threw my tox out the pram one day and said well I'll find you work. If you like painting and decorating and tiling and things, I'll find you work. I've done it for the book keeping; I'll do it for you. It went from me sort of helping out and giving advice and finding the work, to sort of doing all of it. And then it's just steadily grown; overall it's steadily going in the right direction" (Alex, married with children)

I was pregnant with my third child. I was working, doing various concepts, admin and stuff and my husband was working for an estate agent. The estate agent basically went bust and he made him redundant. He made my husband redundant and I'm heavily pregnant with my third child and I said "please go and get a job." He said "nope, I want to start my own business". I said "please do something that you know that we know" and we had already, prior to that, done some bathroom refurbishment works (Zena, married with childrgh)

So I said "Mike, I'm not doing it anymore. I'm nt女 helping you out at all now because I'm sick of it. You either leave Dom (who was his business partner) and go off on your own. I'll help you set it up but you'll have to run it yourself or you just carry on and you will be bankrupt... He had to pay for his half of the mortgage. My husband walked away with nothing (Paula, married)

A combination of factors then occurred, but the main one was that our stepdaughter, Paul's daughter Emma, aged at that stage early 20s, who had been living with us, lef home with her 3-year-old car to go and live in the north of England, and it dawned on us that, despite the fact that she had to been given a very basic maintenance instruction kit from her father, she was going to be quite ill-equipped to sort out and look after her car herself. This caused her father a great deal of stress and when we discussed it jointly, we thought well, women are more likely to pay for services in this area.... We then started to look at how it might possible to offer a package of motoring services specififally fru unmon

The reason I formed $X X X$ was because I was a single parent and my ex-husband didn't pay anything and I was a mother and father, and the sole breadwinner...So I realized it was actually a huge risk to be solely responsible for two children and rely on me to be healthy enough to be in a position to continue to work. My health was suffering through stress, so I started a business called XXX, which wouldn't require me to be the only deliver (Jane, divorced with children)

A lot of the time, probably about $80 \%$ of the time my mo comes in to help out huge amounts. That's kind of where we are. My father does a fair amount of deliveries and things like that when we need someone to deliver but it's my mom that helps out in the showroom most of the time with me. If my mum wasn't so helpful then I probably would struggle a lot more and I'd be pulling a lot longer hours (Caroline, married) 


1
2
3
4
5
6
7
8
9
10
11
12
13
14
15
16
17
18
19
20
21
22
23
24
25
26
27
28
29
30
31
32
33
34
35
36
37
38
39
40
41
42
43
44
45
46
47
48
49
50
51
52
53
54
55
56
57
58
60

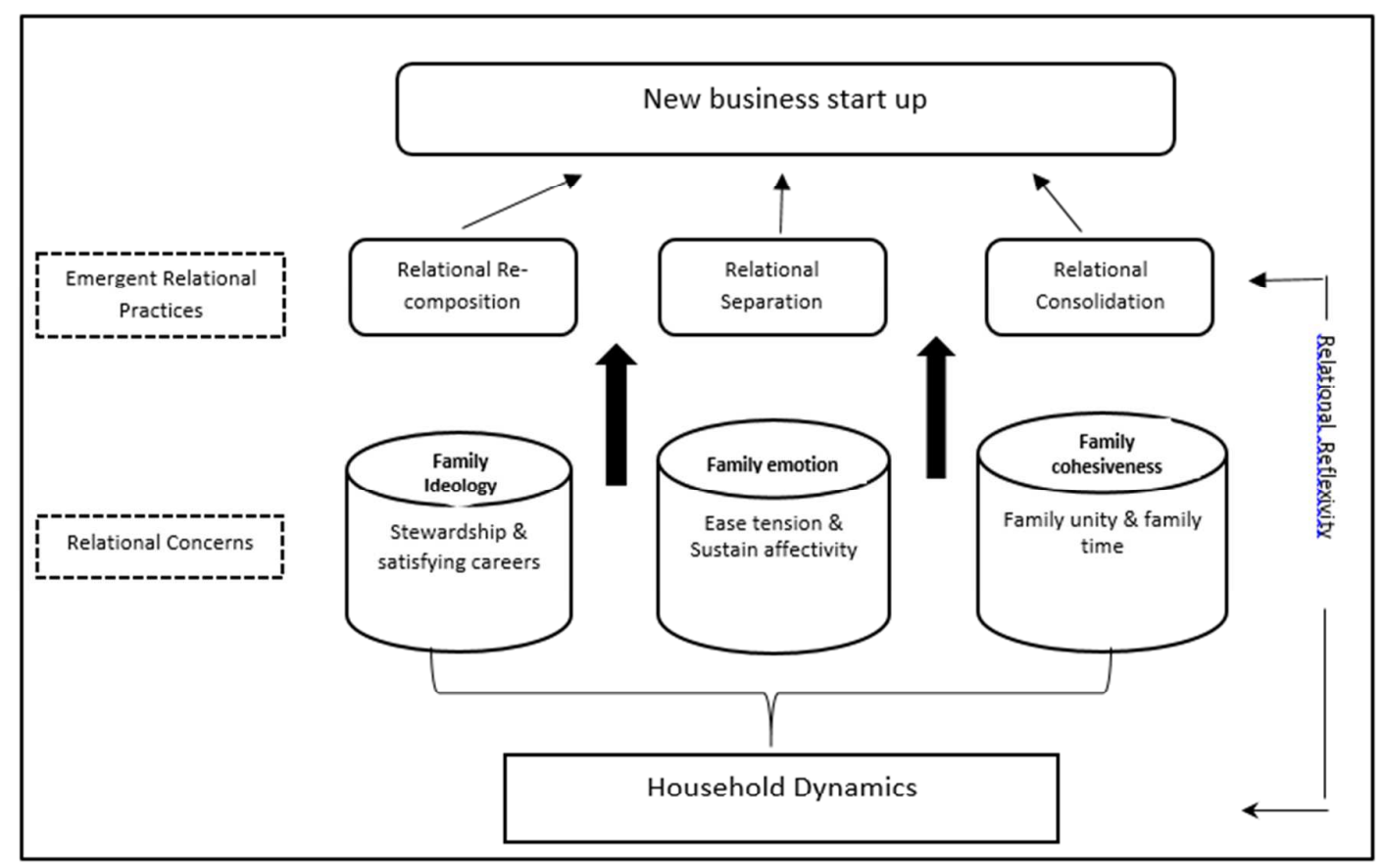

Figure 2. Women entrepreneurs' responses to changing household dynamics 